\title{
Response of Salt-Tolerant Rice Varieties to Biocompost Application in Sodic Soil of Eastern Uttar Pradesh
}

\author{
Akhtar H. Khan ${ }^{1}$, Ashok K. Singh ${ }^{1}$, Mubeen ${ }^{1}$, Sudhanshu Singh ${ }^{2 *}$, Najam W. Zaidi ${ }^{2}$, Uma S. Singh ${ }^{2}$, \\ Stephan M. Haefele ${ }^{3}$ \\ ${ }^{1}$ Department of Crop Physiology, Narendra Deva University of Agriculture and Technology, Kumarganj, India; ${ }^{2}$ International Rice \\ Research Institute, New Delhi, India; ${ }^{3}$ Australian Centre for Plant Functional Genomics, University of Adelaide, Adelaide, Aus- \\ tralia. \\ Email: *sud.singh@irri.org
}

Received October $16^{\text {th }}, 2013$; revised November $13^{\text {th }}, 2013$; accepted November $19^{\text {th }}, 2013$

Copyright (C) 2014 Akhtar H. Khan et al. This is an open access article distributed under the Creative Commons Attribution License, which permits unrestricted use, distribution, and reproduction in any medium, provided the original work is properly cited. In accordance of the Creative Commons Attribution License all Copyrights (C) 2014 are reserved for SCIRP and the owner of the intellectual property Akhtar H. Khan et al. All Copyright (C) 2014 are guarded by law and by SCIRP as a guardian.

\section{ABSTRACT}

Sodic soils have immense productivity potential, if managed through proper technology interventions. Biocompost is prepared by composting pressmud (a sugar industry byproduct) received from cane juice filtration and spent wash received from distilleries through microbial aerobic decomposition and can be used to reclaim sodic soils. Field experiments were conducted during the wet season of 2011 and 2012 to study the effect of incorporation of biocompost in sodic soil with four treatments: T1-Control, T2-Biocompost at $2 \mathrm{t} \mathrm{ha}^{-1}$, T3-Biocompost at $4 \mathrm{t} \mathrm{ha}^{-1}$ and T4-Biocompost at $6 \mathrm{t} \mathrm{ha}^{-1}$. The two promising salt tolerant rice varieties preferred by farmers, Narendra usar 3 and NDR 359 were used as test crops, which can produce yields ranging between $2-4 \mathrm{t} \mathrm{ha}^{-1}$ in soil having a pH range of 9.2 to 10.5. Among the different doses of biocompost tested, application of biocompost at $6 \mathrm{t} \mathrm{ha}^{-1}$ registered highest yields, enabled by a higher biomass, ear bearing tiller (EBT), and grain fertility in both varieties. Narendra usar 3 was more responsive to treatments even at lower doses of biocompost than NDR 359, but NDR 359 yielded slightly higher than Narendra usar 3 in all treatments. Soil health was also improved evidently on better fertility and low soil pH and EC at harvest. Thus, biocompost can be considered as a commercially viable, environmentally acceptable and practically enforceable option for improving the crop productivity and soil fertility status.

\section{KEYWORDS}

Biocompost; Narendra usar 3; NDR 359; Salt-Tolerant Varieties; Sodic Soil

\section{Introduction}

Rice (Oryza sativa L.) is the staple food of 2.7 billion people in the world and cultivated in all the continents except Antarctica, covering tropical and sub-tropical regions between $55^{\circ}$ North and $36^{\circ}$ South in a variety of ecosystems, ranging from favourable irrigated to rainfed uplands and lowlands, flash flood and deep water areas [1]. In recent years, rice occupied about 154 million ha area with an average productivity of $3.83 \mathrm{t} \mathrm{ha}^{-1}$. Rice cultivation is of immense importance to food security of Asia, where more than $90 \%$ of the global rice is produced

${ }^{*}$ Corresponding author. and consumed, and which is the home of about $70 \%$ impoverished people of the world. Rice is essential for feeding the world's population, and is especially important in Asian countries. It plays a major role as a staple food, supporting more than 3 billion people [2].

Salt-affected soils occur across continents and under almost all climatic conditions. More than 800 million ha of land throughout the world are salt affected [3]. Among South Asian countries, India has the largest area (6.73 million ha), followed by Bangladesh (1 million ha). In India alone, 1.4 million ha are characterized by coastal salinity, and inland alkaline (sodic) and saline soils (referred to as "Usar" in the local dialect) cover about 5.33 
million ha. Many of these salt-affected areas are either barren or have very low and unstable productivity, particularly in coastal deltas. Rice has previously been reported as being salt susceptible in the early seedling and reproductive stages $[4,5]$, leading to yield reduction of more than $50 \%$ in crops exposed to $6.65 \mathrm{dS} \mathrm{m}^{-1}$ EC [6]. Salt affected soils often have multiple constraints including high $\mathrm{pH}$, high soluble salts, deficiency and toxicity of one or several micronutrients and poor water holding capacity, leading to low productivity. It causes a billion dollar losses in annual crop production globally.

Soil salinity is a major abiotic stress limiting plant growth and development. In crops known as glycophyte or salt susceptible $[7,8]$, it causes yield losses by depressing the uptake of water, and disturbing mineral and normal metabolism. Salt-affected soils are identified by excessive levels of water-soluble salts, especially sodium chloride $(\mathrm{NaCl})$ [9]. $\mathrm{NaCl}$ is a small molecule which when ionized by water, produces sodium $\left(\mathrm{Na}^{+}\right)$and chloride $\left(\mathrm{Cl}^{-}\right)$ions. Excess $\mathrm{Na}^{+}$in plant cells directly damages membrane systems and organelles, resulting in growth reduction and abnormal development prior to plant death. The toxic ions cause ionic and osmotic stress at the cellular level in higher plants, especially in susceptible germplasm $[10,11]$. Salinity reduces plant growth through osmotic effects and reduces the water uptake, thereby causing a reduction in growth.

There are many effective ways for improving salt-affected land, such as leaching, chemical remediation and phytoremediation $[8,12]$. The remediation of salt-affected soils using chemical agents, including gypsum $\left(\mathrm{CaSO}_{4} \cdot 2 \mathrm{H}_{2} \mathrm{O}\right)$, pyrite $\left(\mathrm{FeS}_{2}\right)$, calcite $\left(\mathrm{CaCO}_{3}\right)$, calcium chloride $\left(\mathrm{CaCl}_{2} \cdot 2 \mathrm{H}_{2} \mathrm{O}\right)$, and organic matter (farmyard manure, green manure, organic amendment and municipal solid waste), was successful in many cases and has been implemented worldwide, being effective and simple [12-15]. Gypsum and pyrite are the most effective reclamation agents for sodic soils, but they are expensive and beyond the reach of poor farmers in rainfed lowland areas. But the physical, chemical and biological properties of soils in salt-affected areas can also be improved by the application of organic matter, leading to enhanced plant growth and development [16,17]. Pressmud, a sugar industry by-product, is readily available in eastern Uttar Pradesh (U.P.) and less expensive compared to gypsum. Biocompost is prepared by composting pressmud received from cane juice filtration and spent wash received from distilleries through microbial aerobic decomposition. It contains nutrients like N, P, K, Zn and big amounts of organic carbon. Calcium replaces $\mathrm{Na}^{+}$ from the cation exchange complex, and about $2 \%-3 \%$ sulphur converts into sulphuric acid and lowers soil $\mathrm{pH}$. In addition, it contains bioagents like Trichoderma and Azatobacter which protect plants from several fungal pathogens, enhance growth and development through robust root formation, and enhance soil $\mathrm{N}$ availability through atmospheric $\mathrm{N}_{2}$ fixation (Table 1). Therefore, use of biocompost can improve the fertility status and chemical properties of sodic soils as well as increase crop yields.

Recently released rice varieties in India, including CSR 36, CSR 43, Narendra usar 3, and NDR 359, have shown great promise for cultivation in sodic/saline soils of Uttar Pradesh and Bihar. In addition, IRRI made considerable progress in developing a Marker Assisted Backcrossing (MABC) system for the major QTL Saltol, associated with salinity tolerance in rice. Through MABC, this locus is now introgressed into three popular varieties (BR11, BRRI dhan 28, and IR64). Trials conducted under field conditions showed that introgression of this QTL significantly improved the salt tolerance of these varieties, and seeds of these three varieties were now ready for testing in farmers' fields. The availability of these salt-tolerant varieties provides a great opportunity for increasing and stabilizing productivity in salt-affected areas. Particularly when combined with best management practices specific for salt-affected areas, salt tolerant rice varieties could become a great opportunity for improving productivity and soil quality of saline and sodic soils. Considering this background, we conducted experiments to evaluate the benefits of combining biocompost and salt tolerant varieties together to harness the sodic soil potential.

\section{Materials and Methods}

The field experiments were conducted during the kharif (wet) season of 2011 and 2012 at the main experiment station of Narendera Deva University of Agriculture and Technology, Kumarganj, Faizabad, India. The experimental site lies between latitude of $26^{\circ} 47^{\prime \prime}$ North and longitude of $82^{\circ} 12^{\prime \prime}$ East, on an elevation of about 113 meters above mean sea level in the Gangetic alluvium of Eastern Uttar Pradesh. The Faizabad district has a semiarid climate, receiving a mean annual rainfall of $1100 \mathrm{~mm}$, and about $80 \%$ of the total precipitation occurs during the monsoon season (July to end of September) with few

Table 1. Average nutrient and carbon concentration in the applied biocompost.

\begin{tabular}{ccc}
\hline S. No. & Element & Concentration (\%) \\
\hline 1$)$ & Nitrogen & $1.0-1.2$ \\
$2)$ & Phosphorus & $2.5-3.2$ \\
$3)$ & Potassium & $1.5-1.8$ \\
$4)$ & Calcium & $1.0-1.2$ \\
$5)$ & Sulphur & $2.0-3.0$ \\
$6)$ & Zinc & $0.025-0.027$ \\
$7)$ & Organic carbon & $10-15$ \\
\hline
\end{tabular}


showers in winter. The soil of the experimental field had a silty clay texture ( $24 \%$ sand, $55 \%$ silt, $21 \%$ clay), $\mathrm{pH}$ 9.3, EC $2.8 \mathrm{dS} \mathrm{m}^{-1}$ and $210,22.5$ and $231.4 \mathrm{~kg}$ of available N, P and $\mathrm{K} \mathrm{ha}^{-1}$, respectively. Soil organic C, N, P, and $\mathrm{K}$ were analyzed by using standard methods [18-21]. The experiment was laid out in a randomized complete block design (RCBD) with three replications, and had four biocompost treatments: T1 Control, recommended doses of $\mathrm{N}-\mathrm{P}_{2} \mathrm{O}_{5}-\mathrm{K}_{2} \mathrm{O}$ at $120-40-40 \mathrm{~kg} \mathrm{ha}^{-1}$ through inorganic fertilizers); T2 Biocompost at $2 \mathrm{t} \mathrm{ha}^{-1}+$ recommended doses of $\mathrm{N}^{-} \mathrm{P}_{2} \mathrm{O}_{5}-\mathrm{K}_{2} \mathrm{O}$ at $120-40-40 \mathrm{~kg} \mathrm{ha}^{-1}$ through inorganic fertilizers; T3 Biocompost at $4 \mathrm{t} \mathrm{ha}^{-1}+$ recommended doses of $\mathrm{N}-\mathrm{P}_{2} \mathrm{O}_{5}-\mathrm{K}_{2} \mathrm{O}$ at $120-40-40 \mathrm{~kg} \mathrm{ha}^{-1}$ through inorganic fertilizers; T4 Biocompost at $6 \mathrm{t} \mathrm{ha}^{-1}$ + recommended doses of $\mathrm{N}_{-} \mathrm{P}_{2} \mathrm{O}_{5}-\mathrm{K}_{2} \mathrm{O}$ at $120-40-40 \mathrm{~kg}$ $\mathrm{ha}^{-1}$ through inorganic fertilizers. The biocompost was brought from the local sugar industry situated in eastern U.P.

Elemental concentrations of biocompost for selected nutrient elements and carbon are given in Table 1. Each treatment was tested with two NDUAT-developed salt tolerant rice varieties, Narendra usar 3 and NDR 359. Narendra usar 3 was released in 2001 with an attainable yield of $2.5-3.0 \mathrm{t} \mathrm{ha}^{-1}$ in sodic soils, whereas NDR 359 was released in 1999 having an attainable yield of 3.0 $3.5 \mathrm{t} \mathrm{ha}^{-1}$ under sodic soil conditions. Both varieties can perform well up to soil $\mathrm{pH}$ values of $9.3-10.1$ with the use of soil amendments like biocompost (pressmud) and gypsum.

In both experimental seasons, biocompost was mixed in the soil 15 days before transplanting and $5 \mathrm{~cm}$ water was continuously ponded in each plot for a week. Thirty days old seedlings were transplanted at $15 \times 20 \mathrm{~cm}$ spacing using 3 seedlings per hill. Full phosphorous and potash and one third of the nitrogen were applied basal one day before transplanting. The remaining two thirds of nitrogen were applied in two equal splits, one at maximum tillering and the other at panicle initiation. Standard recommended cultural practices and plant protection measures were adopted to grow the crop. Observations on various growth parameters, phenology and data on yield and yield components i.e. plant height $(\mathrm{cm})$, biomass per plant $(\mathrm{g}), \mathrm{EBT}$, fertile grains panicle ${ }^{-1}$, sterile grains per panicle ${ }^{-1}, 100$ seed weight $(\mathrm{g})$ and average yield $\left(\mathrm{t} \mathrm{ha}^{-1}\right)$ were recorded at maturity. Plant height, biomass per plant and yield attributes were determined by randomly sampling 10 hills from each plot. Panicles were hand-threshed and the fertile and sterile grains were separated by submerging threshed grains in $10 \%$ saline water. The samples were oven dried at $70^{\circ} \mathrm{C}$ to get constant weight. Ear bearing tiller, 100 grain weight, were then computed. Grain yield was determined on a $10 \mathrm{~m}^{2}$ area marked in the middle of each plot. Grains were harvested, dried, and weighed. Soil samples were taken from the plots before start of the experiment and after harvesting of the experiment. The samples were dried and sieved through a $2 \mathrm{~mm}$ sieve. Subsamples were used to determine the soil $\mathrm{pH}$ and $\mathrm{EC}$ with a 1:5 soil: water suspension. All data were analyzed using standard statistical procedures [22].

\section{Results and Discussion}

Soil samples taken just after harvest showed that biocompost applied at $6 \mathrm{t} \mathrm{ha}^{-1}$ (T4) recorded the highest values of plant available $\mathrm{N}\left(252\right.$ and $\left.260 \mathrm{~kg} \mathrm{ha}^{-1}\right), \mathrm{P}(44.6$ and $\left.47.2 \mathrm{~kg} \mathrm{ha}^{-1}\right)$ and $\mathrm{K}\left(265\right.$ and $\left.266 \mathrm{~kg} \mathrm{ha}^{-1}\right)$ in the year 2011 and 2012, respectively (Table 2). Significant increases of plant available N, P and $\mathrm{K}$ were also achieved with lower biocompost rates (T2 and T3). Biocompost is organic manure, containing nutrients which are released into the soil after decomposition, increasing the plant available $\mathrm{N}, \mathrm{P}$ and $\mathrm{K}$. The total increase in available $\mathrm{N}$ is similar to the total amount of $\mathrm{N}$ applied with the biocompost ( 20 to $24 \mathrm{~kg} \mathrm{~N}$ in $2 \mathrm{t}$ biocompost), but considerable $\mathrm{N}$ was also applied with inorganic fertilizer. Assuming that at least some of the biocompost was decomposed during the season, the soil pool of available $\mathrm{N}$ at the end of the season probably contained $\mathrm{N}$ from the organic and inorganic fertilizer. The observations also indicate that more $\mathrm{N}$ was applied than needed by the crop. Unclear remained if a part of the excessive $\mathrm{N}$ entered unavailable soil $\mathrm{N}$ pools, and if or how much $\mathrm{N}$ had been lost through percolation or gaseous losses. In the case of $\mathrm{P}$, much more $\mathrm{P}$ had been applied then found back in the available $\mathrm{P}$ pool (50 to $64 \mathrm{~kg} \mathrm{~N}$ in $2 \mathrm{t}$ biocompost). Losses of $\mathrm{P}$ are usually small and most of the excess $\mathrm{P}$ entered most likely unavailable soil $\mathrm{P}$ pools. The availability of $\mathrm{P}$ is mainly controlled by soil $\mathrm{pH}$, clay content, calcareousness and organic matter percentage of the soil. Total amount of $\mathrm{K}$ applied with the biocompost was between 30 to $36 \mathrm{~kg} \mathrm{~K}$ per $2 \mathrm{t}$ biocompost, and only a small part of that is found back in the available soil $\mathrm{K}$ pool at the end of the season (Table 2). As in the case of N, part of the $\mathrm{K}$ may have entered unavailable soil $\mathrm{K}$ pools and a part might have been lost through percolation into the subsoil.

The biocompost application also had beneficial effects on soil chemical properties like soil $\mathrm{pH}$, electrical conductivity, and organic carbon content (Table 3). Maximum reduction of soil $\mathrm{pH}$ was observed in $\mathrm{T} 4\left(6 \mathrm{tha}^{-1}\right.$ of biocompost), but the trend of falling $\mathrm{pH}$ was observed in all biocompost treatments and continued across both seasons. Since soil $\mathrm{pH}$ is a soil characteristic indicating an overall picture of the medium for plant growth, including nutrient availability, fate of added nutrients, and sodicity status, this change is very important. Production of inorganic and organic acids (amino acid and humic acid) during mineralization of organic materials by heterotrophs 
Table 2. Effect of different doses of biocompost on plant available N, P, and $\mathrm{K}$ in the top soil (15 $\mathrm{cm})$ at the end of the season.

\begin{tabular}{ccccccc}
\hline \multirow{2}{*}{ Treatment } & \multicolumn{2}{c}{ Available $\mathrm{N}\left(\mathrm{kg} \mathrm{ha}^{-1}\right)$} & \multicolumn{2}{c}{ Available $\mathrm{P}_{2} \mathrm{O}_{5}\left(\mathrm{~kg} \mathrm{ha}^{-1}\right)$} & \multicolumn{2}{c}{ Available $\mathrm{K}_{2} \mathrm{O}\left(\mathrm{kg} \mathrm{ha}^{-1}\right)$} \\
\cline { 2 - 7 } & 2011 & 2012 & 2011 & 2012 & 2011 & 2012 \\
\hline No Biocompost & $211.5 \pm 1.37$ & $212.2 \pm 1.32$ & $24.0 \pm 0.34$ & $25.2 \pm 0.32$ & $234.8 \pm 1.54$ & $235.9 \pm 1.77$ \\
Biocompost $2 \mathrm{t} \mathrm{ha}^{-1}$ & $235.7 \pm 0.98$ & $238.0 \pm 1.12$ & $29.4 \pm 0.56$ & $32.7 \pm 0.39$ & $245.7 \pm 1.07$ & $247.0 \pm 1.54$ \\
Biocompost $4 \mathrm{t} \mathrm{ha}^{-1}$ & $243.3 \pm 1.22$ & $245.0 \pm 0.99$ & $36.2 \pm 0.43$ & $37.7 \pm 0.23$ & $256.5 \pm 1.76$ & $259.0 \pm 1.43$ \\
Biocompost $6 \mathrm{t} \mathrm{ha}^{-1}$ & $252.3 \pm 1.01$ & $260.0 \pm 1.03$ & $44.6 \pm 0.71$ & $47.2 \pm 0.43$ & $264.5 \pm 1.75$ & $265.5 \pm 1.38$ \\
\hline
\end{tabular}

All figures are mean values \pm standard deviation.

Table 3. Effect of different doses of biocompost on soil pH, EC and Organic carbon.

\begin{tabular}{|c|c|c|c|c|c|c|c|c|c|c|c|c|}
\hline \multirow{3}{*}{ Treatment } & \multicolumn{4}{|c|}{$\mathrm{pH}$} & \multicolumn{4}{|c|}{$\mathrm{EC}^{*}\left(\mathrm{~d} \mathrm{Sm}^{-1}\right)$} & \multicolumn{4}{|c|}{ Organic carbon $(\%)$} \\
\hline & \multicolumn{2}{|c|}{ Before transplanting } & \multicolumn{2}{|c|}{ After harvesting } & \multicolumn{2}{|c|}{ Before transplanting } & \multicolumn{2}{|c|}{ After harvesting } & \multicolumn{2}{|c|}{ Before transplanting } & \multicolumn{2}{|c|}{ After harvesting } \\
\hline & 2011 & 2012 & 2011 & 2012 & 2011 & 2012 & 2011 & 2012 & 2011 & 2012 & 2011 & 2012 \\
\hline No Biocompost & 9.3 & 9.3 & 9.3 & 9.2 & 2.8 & 2.7 & 2.7 & 2.7 & 0.40 & 0.40 & 0.40 & 0.40 \\
\hline $\begin{array}{l}\text { Biocompost } \\
2 \mathrm{tha}^{-1}\end{array}$ & 9.3 & 9.1 & 9.2 & 9.0 & 2.8 & 2.7 & 2.7 & 2.7 & 0.40 & 0.41 & 0.43 & 0.44 \\
\hline $\begin{array}{l}\text { Biocompost } \\
4 \mathrm{tha}^{-1}\end{array}$ & 9.3 & 9.1 & 9.1 & 8.9 & 2.8 & 2.7 & 2.7 & 2.7 & 0.40 & 0.42 & 0.46 & 0.45 \\
\hline $\begin{array}{c}\text { Biocompost } \\
6 \mathrm{tha}^{-1}\end{array}$ & 9.3 & 9.0 & 9.0 & 8.8 & 2.8 & 2.7 & 2.7 & 2.7 & 0.40 & 0.42 & 0.47 & 0.48 \\
\hline
\end{tabular}

${ }^{*} \mathrm{EC}=$ Electrical conductivity.

and nitrification by autotrophs would have caused this decrease in soil $\mathrm{pH}$. This effect of organic materials added to sodic soils has been repeatedly described [23]. In parallel, electrical conductivity decreased with the application of biocompost from $2.8 \mathrm{dS} \mathrm{m}^{-1}$ to $2.7 \mathrm{dS} \mathrm{m}^{-1}$ after harvesting of the crop during 2011 , but there was no further decrease in the following season. The underlying process is that the decomposition of organic materials releases acids or acid forming compounds that react with the soluble salts present in the soil and either convert them into insoluble salts or decrease their solubility. In addition, organic matter has a very high exchange capacity and will have removed further cations and anions from the soil solution.

Application of biocompost also increased the very low level of soil organic carbon (only $0.4 \%$ in the control soil; Table 3). This effect was of course strongest in T4 but also occurred if only $2 \mathrm{t}$ biocompost per ha were applied. Organic matter is an important source of nutrients and microbial activity in the soil, improves soil structure, water holding capacity, infiltration rate, aeration and porosity of the soil. Most likely, the high $\mathrm{Ca}^{2+}$ content of the biocompost would also have replaced $\mathrm{Na}^{+}$cations from the exchange complex but we did not determine the sodium absorption ratio. Overall, these results confirm the observations [24], who reported that the increase in organic carbon and decrease in soil $\mathrm{pH}$ and $\mathrm{EC}$ were stronger in organic manured treatments as compared to fertilizers alone. Thus, the biocompost treatments had an overall beneficial effect on soil physical and chemical properties, and increased nutrient availability. The build- up in $\mathrm{N}, \mathrm{P}$ and $\mathrm{K}$ supplies has a residual effect and improves the soils lastingly [25].

The response of both rice varieties to biocompost application was clearly visible during both years although plant height did not differ significantly between treatments. But all treatments significantly influence the yield attributes and yield over the control treatment in both seasons. The beneficial effect of higher doses of biocompost was more pronounced but the effects occurred also at lower doses. The effect of biocompost on plant biomass was found significant at higher doses but the interaction of variety with biocompost was non-significant. In 2012, lower plant height and higher biomass of NDR 359 were recorded as compared with 2011, possibly due to the residual effect of the biocompost (Table 4). In comparison with the control, maximum increase in ear bearing tillers (EBT) (35 and 37\% of Narendra usar 3, and 60 and $21 \%$ of NDR 359 in 2011 and 2012, respectively) was recorded with treatment $\mathrm{T} 4$ (biocompost at $6 \mathrm{t}$ $\left.\mathrm{ha}^{-1}\right)$. Treatment $\mathrm{T} 4$ also increased fertile grains per panicle (32 and 9\% of Narendra usar 3, and 28 and $20 \%$ of NDR 359 in 2011 and 2012, respectively), reduced sterile grains per panicle (37 and $26 \%$ of Narendra usar 3 , and 36 and $54 \%$ and 10 and 7\% of NDR 359 in 2011 and 2012, respectively) (Table 5).

Application of biocompost significantly increased grain yield as a consequence of these effects on yield components, and increasingly so with higher biocompost rates (Figure 1). A higher relative yield increase was recorded in Narendra usar 3, but the actual yield and yield increase was higher in NDR 359 in both experimental years and 
in all treatments. It is logical that a higher dose of biocompost application resulted in a higher $\mathrm{N}, \mathrm{P}$ and $\mathrm{K}$ supply, but the additional biocompost effects on soil $\mathrm{pH}$, conductivity, and soil organic carbon will have further increase nutrient availability to the crop. Other effects could include an increased mineralization of soil organic matter due to the low $\mathrm{C}: \mathrm{N}$ ratio of the biocompost, and possibly plant growth stimulants and beneficial microflora contained in the biocompost [26]. Several other workers also reported the positive cumulative effect of organic manures and the direct effect of fertilizers on rice yields [27-29].

It is clear from the economic analysis (Table 6) which only considered additional costs and gains related to the treatment, that use of biocompost provided additional income as compared with the control (without biocompost application) in case of both varieties. The yield improvement with biocompost ranged between $15 \%$ to $25 \%$ in the salt tolerant Narendra user 3 and between $7 \%$ to $24 \%$ in NDR 359. Higher doses of biocompost (T4, $6 \mathrm{t} \mathrm{ha}^{-1}$ ) produced higher yields than the lower doses $\left(4 \mathrm{tha}^{-1}\right.$ in T3 and $2 \mathrm{t} \mathrm{ha}^{-1}$ in T2), but the combination of costs and gains resulted in highest treatment gains from T3 combined with Narendra user 3. Thus, biocompost application led to a net profit increase of up to Rs. $3900 \mathrm{ha}^{-1}$ per rice crop from a degraded sodic soil.

\section{Conclusions}

The results of the field experiments indicated that the application of biocompost at 2 to $6 \mathrm{t} \mathrm{ha}^{-1}$ in sodic soils 15 days before transplanting enhanced available nutrient contents, thus increasing the overall soil fertility status. The combination of improved soil conditions and applied nutrients caused improved values for yield attributes like ear bearing tillers, sterile grains per panicle, 100 grain weight, and finally grain yield.

Assuming an average yield advantage of $20 \%-30 \%$ over the existing rice yield of $2.9-3.3 \mathrm{tha}^{-1}$, it can contribute to food security and improve the livelihood of rice

Table 4. Plant height $(\mathrm{cm})$ and biomass per plant (g) of two rice varieties in response to different doses of biocompost application in sodic soil.

\begin{tabular}{|c|c|c|c|c|c|c|c|c|}
\hline \multirow[b]{3}{*}{ Treatment } & \multicolumn{4}{|c|}{ Plant height $(\mathrm{cm})$} & \multicolumn{4}{|c|}{ Biomass per plant (g) } \\
\hline & \multicolumn{2}{|c|}{2011} & \multicolumn{2}{|l|}{2012} & \multicolumn{2}{|c|}{2011} & \multicolumn{2}{|l|}{2012} \\
\hline & Narendra usar 3 & NDR 359 & Narendra usar 3 & NDR 359 & Narendra usar 3 & NDR 359 & Narendra usar 3 & NDR 359 \\
\hline No Biocompost & 98.4 & 102.4 & 98.5 & 92.1 & 37.3 & 35.6 & 44.0 & 46.6 \\
\hline $\begin{array}{c}\text { Biocompost } \\
2 \mathrm{t} \mathrm{ha}^{-1}\end{array}$ & 102.9 & 105.1 & 99.5 & 93.5 & 37.7 & 38.7 & 49.0 & 58.4 \\
\hline $\begin{array}{l}\text { Biocompost } \\
4 \mathrm{t} \mathrm{ha}^{-1}\end{array}$ & 103.6 & 106.1 & 101.2 & 93.4 & 41.2 & 43.6 & 51.7 & 61.0 \\
\hline $\begin{array}{l}\text { Biocompost } \\
6 \mathrm{t} \mathrm{ha}^{-1}\end{array}$ & 105.4 & 108.3 & 102.3 & 99.0 & 44.5 & 45.7 & 53.4 & 63.0 \\
\hline $\mathrm{SEm} \pm$ & 1.19 & 1.67 & 1.73 & 2.4 & 0.29 & 0.43 & 1.71 & 2.44 \\
\hline $\mathrm{CD}$ at $5 \%^{*}$ & NS & NS & NS & NS & NS & 1.28 & 5.21 & 7.37 \\
\hline
\end{tabular}

${ }^{*} \mathrm{NS}=$ Non significant.

Table 5. Yield components of the two rice varieties in response to different rates of biocompost application in sodic soil.

\begin{tabular}{|c|c|c|c|c|c|c|c|c|c|c|c|c|c|c|c|c|}
\hline \multirow[b]{3}{*}{ Treatment } & \multicolumn{4}{|c|}{ Ear bearing tillers } & \multicolumn{4}{|c|}{ Fertile grains/panicle } & \multicolumn{4}{|c|}{ Sterile grains/panicle } & \multicolumn{4}{|c|}{100 seed weight $(\mathrm{g})$} \\
\hline & \multicolumn{2}{|c|}{2011} & \multicolumn{2}{|l|}{2012} & \multicolumn{2}{|c|}{2011} & \multicolumn{2}{|c|}{2012} & \multicolumn{2}{|c|}{2011} & \multicolumn{2}{|c|}{2012} & \multicolumn{2}{|c|}{2011} & \multicolumn{2}{|l|}{2012} \\
\hline & $\begin{array}{l}\text { Narendra } \\
\text { usar } 3\end{array}$ & $\begin{array}{c}\text { NDR } \\
359\end{array}$ & $\begin{array}{l}\text { Narendra } \\
\text { usar } 3\end{array}$ & $\begin{array}{c}\text { NDR } \\
359\end{array}$ & $\begin{array}{l}\text { Narendra } \\
\text { usar } 3\end{array}$ & $\begin{array}{c}\text { NDR } \\
359\end{array}$ & $\begin{array}{c}\text { Narendra } \\
\text { usar } 3\end{array}$ & $\begin{array}{c}\text { NDR } \\
359\end{array}$ & $\begin{array}{c}\text { Narendra } \\
\text { usar } 3\end{array}$ & $\begin{array}{l}\text { NDR } \\
359\end{array}$ & $\begin{array}{l}\text { Narendra } \\
\text { usar } 3\end{array}$ & $\begin{array}{c}\text { NDR } \\
359\end{array}$ & $\begin{array}{c}\text { Narendra } \\
\text { usar } 3\end{array}$ & $\begin{array}{c}\text { NDR } \\
359\end{array}$ & $\begin{array}{c}\text { Narendra } \\
\text { usar } 3\end{array}$ & $\begin{array}{c}\text { NDR } \\
359\end{array}$ \\
\hline $\begin{array}{c}\text { No } \\
\text { Biocompost }\end{array}$ & 5.76 & 6.67 & 7.73 & 8.87 & 109.48 & 151.67 & 131.93 & 144.07 & 28.40 & 19.70 & 34.80 & 21.87 & 2.41 & 2.42 & 2.39 & 2.45 \\
\hline $\begin{array}{l}\text { Biocompost } \\
2 \mathrm{t} \mathrm{ha}^{-1}\end{array}$ & 6.94 & 7.28 & 8.13 & 10.07 & 114.38 & 170.34 & 137.80 & 144.33 & 26.60 & 15.20 & 27.93 & 13.33 & 2.45 & 2.44 & 2.45 & 2.48 \\
\hline $\begin{array}{c}\text { Biocompost } \\
4 \mathrm{t} \mathrm{ha}^{-1}\end{array}$ & 7.36 & 8.00 & 9.13 & 10.27 & 131.03 & 186.66 & 138.73 & 162.67 & 20.50 & 14.60 & 26.07 & 10.40 & 2.56 & 2.51 & 2.63 & 2.60 \\
\hline $\begin{array}{c}\text { Biocompost } \\
6 \mathrm{t} \mathrm{ha}^{-1}\end{array}$ & 7.75 & 10.70 & 10.60 & 10.73 & 144.03 & 194.32 & 144.33 & 173.53 & 17.80 & 12.60 & 25.71 & 10.10 & 2.85 & 2.66 & 2.75 & 2.61 \\
\hline $\mathrm{SEm} \pm$ & 0.43 & 0.61 & 0.43 & 0.60 & 1.96 & 2.76 & 4.16 & 5.89 & 0.91 & 1.51 & 0.77 & 1.11 & 0.02 & 0.03 & 0.03 & 0.04 \\
\hline $\mathrm{CD}$ at $5 \%{ }^{*}$ & NS & 1.84 & NS & NS & 5.93 & 8.38 & 12.64 & NS & 2.83 & 4.24 & 2.37 & 3.34 & NS & 0.09 & NS & 0.13 \\
\hline
\end{tabular}

${ }^{*} \mathrm{NS}=$ Non significant. 
Table 6. Economic analysis dependent on treatments and varieties used.

\begin{tabular}{|c|c|c|c|c|c|c|c|}
\hline \multirow{2}{*}{ Treatment } & \multicolumn{2}{|c|}{ Yield increase over control $\left(\mathrm{t} \mathrm{ha}^{-1}\right)$} & \multicolumn{2}{|c|}{$\begin{array}{l}\text { Value of increased yield } \\
\text { (INR) }\end{array}$} & \multirow[t]{2}{*}{$\begin{array}{l}\text { Cost of biocompost } \\
\text { (INR) }^{* *}\end{array}$} & \multicolumn{2}{|c|}{$\begin{array}{l}\text { Additional income obtained with } \\
\text { the use of biocompost (INR) }\end{array}$} \\
\hline & $\begin{array}{l}\text { Narendra } \\
\text { usar } 3\end{array}$ & NDR 359 & $\begin{array}{l}\text { Narendra } \\
\text { usar } 3\end{array}$ & NDR 359 & & $\begin{array}{l}\text { Narendra } \\
\text { usar } 3\end{array}$ & NDR 359 \\
\hline No Biocompost & - & - & - & - & - & - & - \\
\hline $\begin{array}{l}\text { Biocompost } \\
2 \mathrm{tha}^{-1}\end{array}$ & 0.44 & 0.23 & 5632 & 2944 & 2000 & 3632 & 944 \\
\hline $\begin{array}{l}\text { Biocompost } \\
\quad 4 \mathrm{tha}^{-1}\end{array}$ & 0.62 & 0.41 & 7936 & 5248 & 4000 & 3936 & 1248 \\
\hline $\begin{array}{l}\text { Biocompost } \\
6 \mathrm{tha}^{-1}\end{array}$ & 0.72 & 0.76 & 9216 & 9728 & 6000 & 3216 & 3728 \\
\hline
\end{tabular}

${ }^{*}$ Considering market cost of rice $\mathrm{t}^{-1}$ is Indian Rupees (INR) $12,800 .{ }^{* *}$ Considering application cost of biocompost tha ${ }^{-1}$ is INR 1000 .

2011

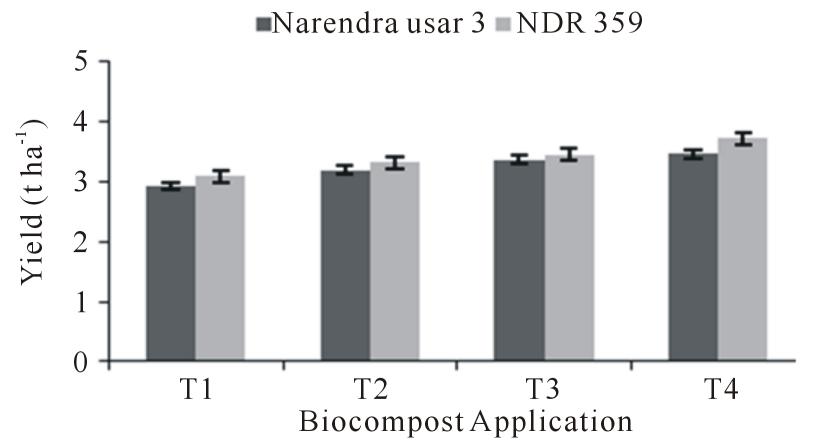

(a)

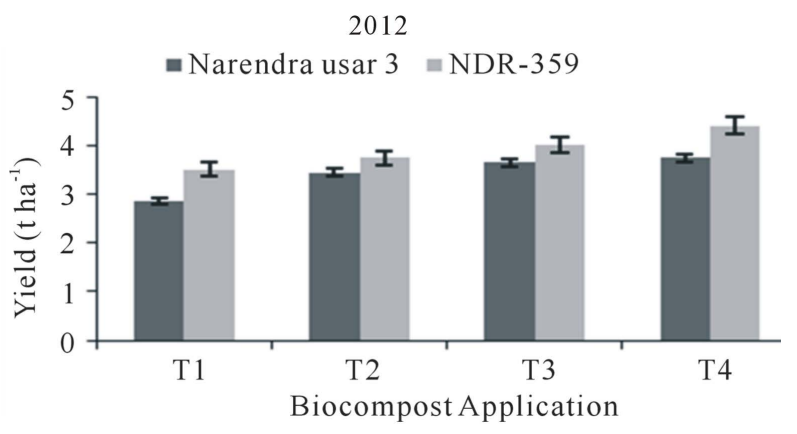

(b)

Figure 1. Effect of different doses of biocompost on grain yield of rice varieties in sodic soil conditions. (T1-No biocompost, T2-Biocompost at $2 \mathrm{t} \mathrm{ha}^{-1}$, T3-Biocompost at 4 $\mathrm{t} \mathrm{ha}^{-1}$ and T4-Biocompost at $6 \mathrm{t} \mathrm{ha}^{-1}$ ).

farmers in rainfed lowlands. By applying nutrient rich biocompost in rice, the farmer may also be benefited in the succeeding crop, getting an additional benefit not evaluated in our study. Thus, application of biocompost can be effectively introduced as an eco-friendly component in the integrated nutrient management system to enhance the soil fertility status and achieve sustainability in crop production in sodic soils of rainfed lowlands.

Treatment dependent yield increases after biocompost applications were highest in Narendra usar 3, but the absolute yield of NDR 359 was still higher in all cases. However, the shorter duration of Narendra usar 3 can be attractive to farmers in cases where late planting and late harvesting cannot be avoided, reducing the attainable yield of the following wheat crop, or where water scarcity at the end of the season is common.

\section{Acknowledgements}

The authors are highly grateful to the Narendra Deva University of Agriculture and Technology for providing technical support for experimental work, including soil analysis, and the European Commission and International Fund for Agricultural Development (EC-IFAD) for providing the financial support as part of the project "Improved rice crop management for raising productivity in the submergence prone and salt affected rainfed lowlands in South Asia".

\section{REFERENCES}

[1] C. Brondani, T. C. O. Borba, P. H. N. Rangel and R. P. V. Brondani, "Determination of Genetic Variability of Traditional Varieties of Brazilian Rice Using Microsatellite Markers," Genetics and Molecular Biology, Vol. 29, No. 4, 2006, pp. 676-684. http://dx.doi.org/10.1590/S1415-47572006000400017

[2] G. S. Khush, "What Will Take to Feed 5.0 Billion Rice Consumers in 2030?" Plant Molecular Biology, Vol. 59, No. 1, 2005, pp. 1-6. http://dx.doi.org/10.1007/s11103-005-2159-5

[3] FAO, "Land and Plant Nutrition Management Services," 2008. http://www.fao.org/agb/agl/agll/spush/

[4] L. Zeng, M. C. Shannon and S. M. Lesch, "Timing of Salinity Stress Affects Rice Growth and Yield Components," Agricultural Water Management, Vol. 48, No. 3, 2001, pp. 191-206. http://dx.doi.org/10.1016/S0378-3774(00)00146-3

[5] F. Moradi and A. M. Ismail, "Response of Photosynthesis, Chlorophyll Fluorescence and ROS Scavenging Systems to Salt Stress During Seedling and Reproductive Stage in Rice," Annals of Botany, Vol. 99, 2007, pp. 1161-1173. 
http://dx.doi.org/10.1093/aob/mcm052

[6] L. Zeng and M. C. Shannon, "Salinity Effects on Seedling Growth and Components of Rice," Crop Science, Vol. 40, 2000, pp. 996-1003.

http://dx.doi.org/10.2135/cropsci2000.404996x

[7] P. M. Hasegawa, R. A. Bressan, J. K. Zhu and H. J. Bohnert, "Plant Cellular and Molecular Responses to High Salinity," Annual Review of Plant Physiology and Molecular Biology, Vol. 51, 2000, pp. 463-499. http://dx.doi.org/10.1146/annurev.arplant.51.1.463

[8] M. Qadir, J. D. Oster, S. Schubert, A. D. Noble and K. L. Sahrawat, "Phytoremediation of Sodic and Saline-Sodic Soils," Advances in Agronomy, Vol. 96, 2007, pp. 197247. http://dx.doi.org/10.1016/S0065-2113(07)96006-X

[9] K. K. Tanji, "Salinity in the Soil Environment," In: A. Lauchli and U. Luttge, Eds., Salinity Environment-PlantMolecules, Kluwer Academic, Dordrecht, 2002, pp. 2151.

[10] M. M. F. Mansour and K. H. A. Salama, "Cellular Basis of Salinity Tolerance in Plants," Environmental and Experimental of Botany, Vol. 52, 2000, pp. 113-122. http://dx.doi.org/10.1016/j.envexpbot.2004.01.009

[11] V. Chinnusamy, A. Jagendorf and J. K. Zhu, "Understanding and Improving Salt Tolerance in Plants," Crop Science, Vol. 45, 2005, pp. 437-448. http://dx.doi.org/10.2135/cropsci2005.0437

[12] B. R. Sharma and P. S. Minhas, "Strategies for Managing Saline/Alkali Waters for Sustainable Agricultural Production in South Asia," Agricultural Water Management, Vol. 78, 2005, pp. 136-151. http://dx.doi.org/10.1016/j.agwat.2005.04.019

[13] J. P. Mitchell, C. Shennan, M. J. Singer, D. W. Peters, K. O. Miller, T. Prichars, S. R. Grattan, J. D. Rhoadesh, D. M. May and D. S. Munk, "Impacts of Gypsum and Winter Cover Crops on Soil Physical Properties and Crop Productivity When Irrigated with Saline Water," Agriculture Water Management, Vol. 45, 2000, pp. 55-71. http://dx.doi.org/10.1016/S0378-3774(99)00070-0

[14] A. Hanay, F. Buyuksonmez, F. M. Kiziloglu and M. Y. Canbolart, "Reclamation of Saline-Sodic with Gypsum and MSW Compost," Compost Science and Utilization, Vol. 12, 2004, pp. 175-179. http://dx.doi.org/10.1080/1065657X.2004.10702177

[15] M. Tejada, C. Garcia, J. L. Gonzalez and M. T. Hernandez, "Use of Organic Amendment as a Strategy for Saline Soil Remediation: Influence on the Physical, Chemical and Biological Properties of Soil," Soil Biology and Biochemistry, Vol. 38, 2006, pp. 1413-1421. http://dx.doi.org/10.1016/j.soilbio.2005.10.017

[16] O. P. Choudhary, A. S. Josan, M. S. Bajwa and L. Kapur, "Effect of Sustained Sodic and Saline-Sodic Irrigation and Application of Gypsum and Farmyard Manure on Yield and Quality of Sugarcane Under Semi-Arid Conditions," Field Crops Research, Vol. 87, 2004, pp. 103-116. http://dx.doi.org/10.1016/j.fcr.2003.10.001

[17] V. N. L. Wong, R. C. Dalal and R. S. B. Greene, "Carbon Dynamics of Sodic and Saline Soil Following Gypsum and Organic Material Additions: A Laboratory Incuba- tion," Applied Soil Ecology, Vol. 41, 2009, pp. 29-40. http://dx.doi.org/10.1016/j.apsoil.2008.08.006

[18] A. J. Walkley and I. A. Black, "Estimation of Soil Organic Carbon by Chromic acid Titration Method," Soil Science, Vol. 34, 1934, pp. 29-38. http://dx.doi.org/10.1097/00010694-193401000-00003

[19] R. C. Linder, "Rapid Analytical Method for Some of the More Common Inorganic Constituents of Plant Tissue," Plant Physiology, Vol. 19, 1944, pp.76-89. http://dx.doi.org/10.1104/pp.19.1.76

[20] C. S. Piper, "Vanado-Molybdo-Phosphoric Yellow Colour Method," Soil and Plant Analysis, Interscience Publication, New York, 1966, p. 368.

[21] M. L. Jackson, "Soil Chemical Analysis," Prentice-Hall of India pvt. Ltd., New Delhi, 1973, pp. 281-285.

[22] V. G. Panse and P. V. Sukhatme, "Statistical Methods for Agricultural Workers," 4th Edition, ICAR, New Delhi, 1985, p. 347.

[23] P. J. A. van Asten, J. A. van't Zelfde, S. E. A. T. M. van der Zee and C. Hammecker, "The Effect of Irrigated Rice Cropping on the Alkalinity of Two Alkaline Rice Soils in the Sahel," Geoderma, Vol. 119, No. 3-4, 2004, pp. 233247. http://dx.doi.org/10.1016/j.geoderma.2003.08.002

[24] A. Kumar and D. S. Yadav, "Use of Organic Manure and Fertilizers in Rice (Oryza sativa) Wheat (Triticum aestivum) Cropping System for Sustainability," Indian Journal of Agricultural Sciences, Vol. 65, No. 10, 1995, pp. 703707.

[25] A. Kumar, H. P. Tripathi and D. S. Yadav, "Correcting Nutrient Imbalances for Sustainable Crop Production," Indian Journal of fertilizers, Vol. 2, No. 11, 2007, pp. 3744.

[26] B. B. Saliha, S. Krishnakumar, and S. K. Natarajan, "Response of Rice Crop to Organic Manuring in High $\mathrm{pH}$ Soil," Asian Journal of Plant Sciences, Vol. 4, No. 5, 2005, pp. 524-526.

http://dx.doi.org/10.3923/ajps.2005.524.526

[27] H. P. Tripathi, A. K. Mauriya and A. Kumar, "Effect of Nitrogen Nutrient Management on Rice-Wheat Cropping System in Eastern Plain Zone of Uttar Pradesh," Journal of Farming System Research and Development, Vol. 13, No. 12, 2007, pp. 198-203.

[28] L. D. Bi, B. Zhang, L. G. R. Liu, Z. Z. Li, Y. R. Liu, C. Ye, X. C. Yu, T. Lai, J. G. Zhang, J. M. Yin and Y. Liang, "Long-Term Effects of Organic Amendments on the Rice Yields for Double Rice Cropping Systems in Subtropical China," Agriculture Ecosystems and Environment, Vol. 129, 2009, pp. 534-541. http://dx.doi.org/10.1016/j.agee.2008.11.007

[29] P. C. Ram, P. N. Singh, O. P. Verma, A. Ismail, N. Singh, A. Srivastava, S. P. Singh and R. K. Singh, "Improving Water and Land Productivity through Technology Integration in Saline Sodic Soils of Indo-Gangatic Basin," Proceedings International Forum on Water and Food, CGIAR Challenge Program in Water and Food, Addis Ababa, 10-14 November 2008, pp. 163-166. 